\section{Working smart to win back lost customers the role of coping choices and justice mechanisms}

\section{Working smart to win back lost customers}

\author{
Annie H. Liu
}

Department of Marketing, Texas State University, San Marcos, Texas, USA

Richa Chugh

School of Marketing and International Business, Victoria University of Wellington, Wellington, New Zealand, and

\section{Albert Noel Gould}

Department of Management, University of Wisconsin - Eau Claire, Eau Claire, Wisconsin, USA
Received 20 October 2014 Revised 8May 2015

2 July 2015

Accepted 7 July 2015

\begin{abstract}
Purpose - The purpose of this paper is to examine how the cognitive appraisals, coping choices and behavioral responses by business-to-business (B2B) sales professionals confronting the acutely stressful experience of losing a customer, and their pursuit of justice in the win-back process, influences reacquisition outcomes. The paper further examines the role of sales experience as a moderator between coping choices and successful win back.

Design/methodology/approach - In all, 98 critical incidents were reported by sales professionals from B2B firms across various industries. NVivo 9, content analysis and logistic regression were used to analyze the data.

Findings - The results show that problem-focused coping (PFC) and pro-active responses positively affect win-back outcome. By contrast, emotion-focused coping (EFC) and re-active responses have a negative association with customer reacquisition. The findings also show that sales experience moderates the relationship between levels of EFC and win-back outcomes. Specifically, for sales professionals with low levels of $\mathrm{EFC}$, sales experience helps improve chances of winning back lost customers. But for sales professionals using higher levels of EFC, more sales experience decreases win-back probability. Additionally, the findings show that procedural, interactional and distributive justice all contribute to successful customer reacquisition.

Research limitations/implications - The few published studies of how B2B sales professionals deal with customer defections reveal a mixture of bereavement and drivenness in striving for new accounts. The authors' focus and findings on the use of PFC and EFC strategies, justice mechanisms and the uneven role of experience in responding to this stressful context suggests that there is much to be gained from additional research. Specifically, probes into how sales professionals may be inadvertently skewed to EFC behaviors by either overly simplistic training systems, learning- versus performance-based incentives or their experience with prior customer defections.

Practical implications - The findings highlight the importance of PFC strategies and the delivery of procedural, interactional and distributive justice strategies to productively adapt to customer defections, activate switch back behavior and win back lost customers. Sales force training systems need to address the increased churning in B2B markets and integrate win-back procedures in sales
\end{abstract}

All authors contributed equally. The authors wish to thank the Associate Editor and two anonymous reviewers for their helpful suggestions. 
$\mathrm{EJM}$

$50,3 / 4$

398

training programs so that sales professionals do not default to EFC and/or strive for new accounts when facing the stress of customer defection.

Originality/value - The findings contribute to customer defection management and sales literature by integrating coping and justice theories in exploring sales professionals' cognitive appraisals and coping responses to the acute stress of losing a current customer.

Keywords Coping, Justice theory, Customer reacquisition, Stressful sales situations, Win-back Paper type Research paper

\section{Introduction}

Change, loss, stress and coping. These seem the measure of our times (Becker, 2013; Kabat-Zinn, 2013). They also describe some of the toughest moments for business-to-business (B2B) sales professionals: that is, losing an existing customer to competition or the other stressors of disruption and discontinuity in markets (Leach and Liu, 2014). Some liken it to divorce and bereavement (Goodwin et al., 1997, p. 167). Due to increased churning in B2B markets, Reichheld's (1996) finding that many firms lose half their customers every five years is now likely an understatement.

Customer defections can create multiple problems for the dismissed supplier: from depressed forecasting and the resulting turbulence with stakeholders to negative word of mouth and a shadow over its reputation. As a result, B2B sales professionals who lose accounts may be concerned about losing more than the commissions.

Worst yet, surveys show that some sales professionals face this stressful situation without the benefit of a company response and win-back strategy (Leach and Liu, 2014). Many firms do not track lost customers to learn from the experience, determine which competitor(s) may be profiting from it or to initiate reacquisition efforts (Griffin, 2007; Reichheld, 1996). In a recent survey, only 25 per cent of dissatisfied buyers who dismissed their sellers reported receiving an apology. Less than 20 per cent of defected buyers indicated that their former supplier tried to stay in touch, for example, "actively waiting" for another opportunity to regain the business (Griffin, 2007; Leach and Liu, 2014).

What makes lapses in "customer defection management" even worst are estimates that as much as 70 per cent of all sales come from current customers (Griffin, 2007). And not only does it cost more time and money to acquire a new customer than to renew one, but also it may be as much as five times harder to get an order from a new customer than a previous customer who has been won back (Griffin and Lowenstein, 2001). The contrast is clear. A single lost customer can spur additional and systemic losses. But if won back, then it can be the source of increased revenues as the renewed relationship and related corporate learning adds to sales beyond the focal account (Griffin and Lowenstein, 2001; Leach and Liu, 2014).

This paper explores how B2B sales professionals choose to cope with the stress of losing a current customer and implement win-back strategies. This is accomplished by critical incident interviews with B2B sales professionals in New Zealand who faced this acutely stressful situation. Our study builds on decades of research into the role and result of stress and coping in sales performance (Behrman and Perreault, 1984; Goolsby, 1992; Lewin and Sager, 2008, 2009, 2010; Naletelich et al., 2014). We integrate the "coping style" and "coping behavior with an acutely stressful event" perspectives outlined by Srivastava and Sager (1999). We further explore if the length of sales experience acts as 
a moderator of coping choices. Additionally, we incorporate the role of procedural, interactive and distributive justice in win back.

Sales professionals facing customer defection usually confront two sequential sense and respond processes:

(1) the internal appraisal and choice of how to cope with the negative event [i.e. coping mechanisms including problem-focused coping (PFC) and emotionfocused coping (EFC)]; and

(2) the external response of attempting to win back the lost customer (i.e. developing and pursuing win-back strategies), hence the importance of justice to restore equity and rebuild relationships.

This paper adds to the win-back literature by exploring the relationship between how $\mathrm{B} 2 \mathrm{~B}$ sales professionals choose to cope with the stress of losing customers and the course and results of their choices for customer reacquisition. While stress and coping have long been studied in the sales literature, the acutely stressful event of losing a B2B customer has received slight attention (Goodwin et al., 1997; Mallin and Mayo, 2006; Mayo and Mallin, 2010). We also contribute to B2B customer defection management by integrating justice theory with sales professionals' coping and response choices.

We proceed with a review of relevant research on stress, coping and justice theories, which guided our hypotheses development. The paper then turns to methodology, analysis and findings. It concludes with managerial implications and the limitations of our study that recommend future research.

\section{Literature review and hypotheses development}

\subsection{Internal response and coping choices}

In B2B sales, stress can be defined as an undesirable change or threat of negative change by customers requiring adaptation by the sales professionals and their organizations (Blaney, 2013; Schneiderman and McCabe, 2013). The undesirable change is the loss of a customer (Kabat-Zinn, 2013). Losing a customer can affect sales professionals' job performance by its emotional toll, sometimes similar to devastating family loses (Goodwin et al., 1997; Mallin and Mayo, 2006, 2010). Two crucial internal responses mediate how sales professionals choose to adapt. The first is cognitive appraisal and the second is coping (Lazarus and Folkman, 1984). The cognitive process begins with the primary appraisal: evaluating the potential costs and benefits. In the secondary appraisal, the sales professional considers ways to prevent or minimize the apparent costs and increase and secure the possible relief or rewards:

Various coping options are evaluated, such as altering the situation, accepting it, seeking more information or holding back from acting impulsively and in a counterproductive way. Primary and secondary appraisals converge to determine whether [the stressful context] is regarded as significant for well-being, and if so, whether it is primarily threatening (containing the possibility of harm or loss) or challenging (holding the possibility of mastery or benefit) (Folkman et al., 1986, p. 933).

2.1.1 Problem-focused coping versus emotion-focused coping. Folkman et al. (1986) further define coping as having two dominant strategies: PFC and $\mathrm{EFC}$. PFC has been described as purposeful problem-solving through rational and deliberate efforts to confront and remedy the stressful situation (Lewin and Sager, 2008; Strutton and 
EJM

$50,3 / 4$

400

Lumpkin, 1993). An example of PFC in attempting to win back a lost customer is, first, analyzing the reason(s) for the defection; second, reviewing the customer's transaction history; third, utilizing remaining relationships in the defected firm to better understand the defection and the possibilities of reacquisition, including seeking allies in the buying center; and fourth, presenting a new value proposition that betters the previous deal. This is a win-back strategy known as "active waiting" (Leach and Liu, 2014).

$\mathrm{EFC}$ encompasses attempts to control or regulate strong emotional reactions to stressful situations by detaching or distancing from the sources of stress or avoiding the situation completely (Folkman et al. 1986; Srivastava and Sager, 1999). EFC may range from denial to seeking the emotional support of colleagues and sales managers, that is, solace versus solutions (Strutton and Lumpkin, 1993). Examples include leaving the office to play golf or start drinking with friends: for example, avoidance on the greens or commiseration in the bar. In either case, the rationalization for retreat may be "churning happens" followed by a resolve to start looking for new accounts. Yet this ignores the potential reverberations from the defected customer and the additional costs of finding a new one. As Goolsby (1992, p. 158) notes:

Generally, emotion-focused coping is defined by passive or reactive strategies, as the individual reduces efforts to control the experience [i.e. does not see it as a "problem to be solved']. Because [the] stress evolves unabated, emotion-focused coping strategies generally have negative outcomes for the individual, even though the individual may sense a temporary reprieve.

In general, $\mathrm{PFC}$ represents people "high in hardiness" who have low alienation from self and work, low powerlessness and high internal locus of control. By contrast, EFC persons may be "high in helplessness", believe they have "no control" and exhibit "a withdrawal disposition" (Tapp, 2013, pp. 290-291). Marketing and sales research has consistently found that PFC results in better job performance, less emotional exhaustion or burnout and less turnover (Goolsby, 1992; Lewin and Sager, 2008, 2009, 2010). The availability or lack of positive response resources can greatly influence which particular coping strategy is selected (Kabat-Zinn, 2013). Helpful resources include a firm's strong customer orientation and problem-solving support by management (Schwepker and Good, 2012). Naletelich et al. (2014, p. 10) suggest that sales managers take measures to help sales professionals "supplant EFC with PFC".

For clarity purposes, we note that once a sales professional chooses PFC, its next steps may be similar to what has been defined as a "learning orientation" in achievement situations: that is, the desire to learn to improve and respond to the problem (DeGeest and Brown, 2011; Morris et al., 2003). Further applying the concepts of goal and achievement research, when a sales professional chooses EFC, it may exhibit a maladaptive behavior in "performance orientation" by turning away to avoid negative feedback (Morris et al., 2003). Yet the key difference is that PFC and EFC are adaptations to stressful change and loss, whereas learning and performance orientations have traditionally been described as predispositions or responses to achievement situations, particularly those focused on learning. However, once a sales professional chooses PFC to win back a defected customer, some principles and practices of learning orientation may begin. Conversely, a sales professional choosing EFC may avoid the customer completely along with any potential for learning. Goodwin et al. (1997) described this withdrawal and avoidance reaction in one of the few studies of how sales professionals respond to lost sales: 
No salesperson [interviewed] attempted to change the situation directly by regaining the specific lost sale; in fact, some emphasized not "badgering" the account. Some reported efforts to regain the lost income, particularly with short-term workaholism, but most interviews emphasized emotion focused coping (Goodwin et al., 1997, p. 173).

In sum, as a general rule, $\mathrm{PFC}$ is an active, hardiness response to stress that attempts to address and solve the stressor (i.e. customer defection issues). High levels of PFC tend to positively influence sales professionals' work outcomes and assist them in developing positive solutions to winning back lost customers. By contrast, EFC can be viewed as a negative and helplessness-driven re-action, for example, reacting to the customer's defection with avoidance or withdrawal behavior. From this, we hypothesize:

H1. A sales professional who uses high (versus low) level of problem-focused coping is more likely to win back a lost customer.

H2. A sales professional who uses high (versus low) level of emotion-focused coping is less likely to win back a lost customer.

2.1.2 Sales experience as a moderator. Scholars suggest that a person predisposed to EFC may adapt and change to PFC for a number of reasons: for example, the stress becomes too great and "survival energy" leads to an active response; new information about the stressor and potential solutions develop; or increased self-awareness and positive reflections support this new direction (Kabat-Zinn, 2013; Srivastava and Sager, 1999).

Past research has showed that "experience" - for example, more than five years in sales - may allow veteran sales professionals to better manage stress and avoid emotional exhaustion and/or quitting their jobs (Goolsby, 1992). Goodwin et al. (1997) reasoned that:

[Sales professionals] who are experienced may benefit from environmental factors (e.g. greater access to senior management, job security), from socialization as sales persons, or from personality traits that promoted resilience at earlier career stages (p. 176, emphasis added).

From this, we hypothesize:

H3. Sales experience may buffer the negative effect of emotion-focused coping on win-back outcomes.

\subsection{The external response and justice theory}

As churning increased in B2B channels, marketing and sales researchers have explored and prescribed justice theory to restore troublesome or terminated exchange relationships (Blodgett et al., 1997; Tax and Brown, 1998; Tax et al., 1998). Justice theory emphasizes equity, that is, fairness, equality and consistency in dealing with exchange partners. Fairness principles can ease resentment to discontinuous events, such as negative price disparities or service/product failures (Folger and Skarlicki, 1999; Homburg and Fürst, 2005; Korsgaard et al., 1995; Tax et al., 1998).

Most scholars exploring the workings of justice theory in the equitable restoration of exchange relationships describe it as a three-dimensional construct consisting of:

- Procedural justice: This involves engaging the exchange partner in a mutually understood, authentic and transparent process of information-seeking from and voice-giving to the customer. By listening, learning and responding with new 
$\mathrm{EJM}$

$50,3 / 4$

402

relational systems and economic distributions, sales professionals may be able to restore equity and trust in the exchange relationship (Hoppner et al., 2014; Tax et al., 1998).

- Interactional justice: This involves the interpersonal values, skills and delivery of honest, polite, empathetic and respectful communications. This is sometimes called the human side of justice (Tax and Brown, 1998).

- Distributive justice: This involves the delivery of fair economic outcomes to remedy interruption(s) in the anticipated economic distributions. These may take the form of price discounts, promotional allowances and other concessions and may temporarily exceed the previous exchange bargain to restore equity and possibly increase loyalty (Brown et al., 2006; Griffith et al., 2006);

We suggest that the three key justice issues in win back are: first, did the sales professional put in the same or greater amount of effort as the lost customer in reviewing the reasons for the defection and possible resolutions (i.e. equity)? Second, did the sales professional's design and delivery of the win-back process and offer meet the customer's concerns and restated requirements (i.e. consistency)? And third, did the defected customer continue to receive as good or better offers/outcomes compared to previous dealings with the firm (i.e. equality)?

$\mathrm{B} 2 \mathrm{~B}$ studies suggest that distributive justice is both the goal and reason for successfully performing B2B relationships. However, some B2B justice researchers posit that procedural justice may be more important than distributive justice because of the cooperative, normative and corrective processes it maintains as exchange partners face competition, complexity and discontinuity together (Brown et al., 2006; Griffith et al., 2006; Hoppner et al., 2014).

2.2.1 Procedural justice. Procedural justice is seen as underpinning the coalescing, relationship-building processes; it continues to be crucial and is refocused and restated when relationship disappointments occur (Griffith et al., 2006; Hoppner et al., 2014). Justice-driven win-back strategies both renew and expand the original workings of procedural justice that first built and guided the buyer-seller relationship.

Alexander and Ruderman (1987) identified three measures of procedural justice: meta-procedural activities, allocation procedures and appeal procedures. Meta-procedural activities consist of rules and processes that are intended to direct allocation and appeal procedures. Allocation procedures are used to distribute outcomes. Appeal procedures refer to processes that recipients can use to try to change the allocations that have occurred (Beugré, 1998). Scholars suggest that procedural justice signifies consistency and helps in establishing common understanding, shared sense-making and expectations (Monin et al., 2012). Because of this, a buyer receiving high levels of procedural justice maybe more willing to continue the relationship (Liu et al., 2012).

Defected customers will look for important procedural justice indicators such as proactive and consistent, customer-focused processes to establish common understanding. Prior research suggests that sales professionals can use "active waiting" to engage defected customers in an information-seeking, voice-giving process to restore equity and trust (Leach and Liu, 2014). By monitoring the customer's continuing business needs, sales professionals can present a worthy win-back offer in line with the customer's priorities for the next purchasing cycle. Tracking the customer's and its new 
supplier's (i.e. the competitor's) actions, sales professionals can provide the defected customer an outlet to voice old and new concerns, wait for the competitor to falter and re-align value propositions. Overall, procedural justice can facilitate better feedback loops on design, production, delivery and use in line with customers' needs. By this, the dismissed supplier can improve service and/or production processes and capabilities and make a successful win-back offer (Tax et al., 1998). With this mind, we hypothesize that:

H4. A sales professional who uses procedural justice (versus one that does not) is more likely to win back a defected customer.

2.2.2 Interactional justice. Interactional justice focuses on providing socially fair treatment (Beugré, 1998). It has two elements: interpersonal and informational justice. Interpersonal justice is largely determined by the degree of politeness, empathy and respect provided during review procedures and delivery of outcomes (Newberg and Waldman, 2012). Informational justice refers to providing reasonable and consistent explanations and information about why and how outcomes were delivered (Colquitt et al., 2001; Liu et al., 2012).

Sales professionals can provide interactional justice to defected customers through customer-oriented communication with honesty, politeness and empathy, as well as listening effectively and providing reasonable and consistent explanations for the firm's failure to retain the customer. Demonstrating respect for customer's concerns by empathetically and effectively communicating with them can also influence perceptions of interactional justice (Beugré, 1998). Newberg and Waldman (2012) prescribe these communication strategies to resolve conflict and build trust and add that engaged listening and appreciation for customer feedback may lead to increased sales. Sales professionals who increase customer perceptions of fairness can successfully restore challenged relationships (Duffy et al., 2013). These interactional justice strategies are similar to what negotiation literature calls "appreciative moves", which may help break a stalemate and re-open negotiations by fostering trust (Kolb and Williams, 2001, pp. 94-95). Thus, sales professionals who provide interactional justice are more likely to re-establish the terminated exchange relationship. Accordingly, we hypothesize that:

H5. A sales professional who uses interactional justice (versus one that does not) is more likely to win back a defected customer.

2.2.3 Distributive justice. Distribute justice is defined by the practical and measurable outcomes of win-back efforts (Sparks and McColl-Kennedy, 2001). Accordingly, distributive justice often takes the form of concessions such as discounts, promotional allowances, financial compensation, refunds, repairs and/or replacements (Tax et al., 1998). Appropriate concessions may help neutralize a customer's negative perceptions and/or reverse deleterious actions. However, situation-specific strategies and metrics for the right amount of concessions and/or compensation to recover and renew the relationship are somewhat ambiguous and undefined (Sparks and McColl-Kennedy, 2001; Sparks and Callan, 1997). So while the concept of distributive justice is often linked to monetary compensation and, thus, appears to be easily calculated, research suggests that the procedures and interactions that lead up to the offer of distributive justice - and their effectiveness in repairing the relationship - can influence the customer's interpretation and response to the distributive offer (Sparks and McColl-Kennedy, 2001). 
EJM

$50,3 / 4$

404

As noted by Hoffman and Kelley (2000), procedural and interactional justice are more crucial than distributive justice when long-term customer relationships are at stake. Similarly, Choi and Choi (2014) did not find support for the universally significant influence of distributive justice during recovery encounters. They suggest that distributive justice only has a strong influence on customer decisions after a severe service failure. Fundamentally, distributive justice alone may not be sufficient to resolve customers' concerns. More importantly, concessions and discounts tend to activate price wars among competitors, which may have a boomerang effect on customer reacquisition (Liu et al., 2015). Therefore, a buyer's perceptions of procedural and interactional justice may have a stronger influence on relationship quality than perceptions of distributive justice (Kumar et al., 1995). Nonetheless, a salesperson seeking to win back a lost customer may use distributive justice mechanisms to motivate the defected customer to reciprocate by renewing the relationship. Thus, where distributive disappointments break up a buyer-seller relationship, distribute justice mechanisms like concessions, discounts and allowances will be crucial. Considering this specific situation, we hypothesize:

H6. A sales professional who uses distributive justice (versus one that does not) is more likely to win back a defected customer.

\section{Methodology}

\subsection{Data collection procedure}

The goal of this research is to gain in-depth knowledge of cognitive and behavioral steps taken by sales professionals when formulating strategies for win back. We conducted critical incident interviews to uncover types of coping strategies and justice mechanisms used by sales professionals when attempting to reacquire lost customers. Critical Incident Technique (CIT), as a qualitative method, is particularly valuable in identifying categories and typologies (Bitner et al., 1990). It involves the use of specific stories and incidents that are content analyzed with the purpose of identifying emergent themes and patterns. CIT is generally used to increase knowledge in an exploratory fashion (Bitner et al., 1990). As research in the area of customer reacquisition is sparse, we aim to develop insights from these specific stories and incidents to identify patterns and behaviors leading to customer reacquisition. In particular, the primary objective was to obtain in-depth knowledge about the strategies sales professionals use during the customer win-back process.

Critical incident interviews were conducted with 56 B2B sales professionals selected from a convenience sample developed by a university's network in New Zealand. Respondents were pre-screened to ensure that knowledgeable and appropriate individuals were selected (Johnston et al, 1999). To obtain a more comprehensive overview, sales professionals from various industries were included. Each interview was conducted face-to-face and followed the same interview protocol. In the course of each interview, B2B sales professionals were asked to describe in detail two incidents focusing on defected customers and win-back efforts: first, an incident where they successfully won back a lost customer; and second, an incident where they were unsuccessful. Respondents provided the following information: reasons for the customer's defection, the sales professional's emotional and behavioral response, and strategies used in the process to reacquire the customer. 


\subsection{Operationalization of constructs}

3.2.1 Coping constructs. Data were analyzed using NVivo9 with content analysis. The first step was to decide on the unit of analysis which was systematically identified across the data set (Wilkinson, 2004). As coping is contextual (Folkman et al., 1986), we identified each critical incident as a unit of measurement (successful or unsuccessful win back). As recommended by Bitner $e$ t al., (1994), a necessary step after deciding the unit of analysis is to create detailed description of category definitions. To ensure construct validity, the coping strategy and justice mechanism constructs were operationalized and classified according to a priori categories derived from literature (Dubois and Gibbert, 2010). Specifically, the coding schemes for coping strategies were adapted from previous work in psychology and marketing (Folkman et al., 1986; Strutton and Lumpkin, 1993), and justice mechanisms were based on Duffy et al.'s (2013), Hoppner et al.'s (2014) and Tax et al.'s (1998) categorization of three justice mechanisms. To enhance internal reliability, multiple analyses of interview transcripts were conducted as recommended by Eisenhardt (1989) until all authors agreed on the coding. The interpretation of data, coding and results were discussed, reviewed and agreed upon by all authors.

PFC is defined as purposeful problem-solving with a commitment to respond to challenges, provide remedy to stressful situations and have an optimistic outlook (Folkman et al., 1986; Strutton and Lumpkin, 1993). The following is an example of PFC by a Sales and Marketing Manager of a Food Ingredient Manufacturer dealing with customer loss by first reviewing customer's transaction history and then making rational efforts to find solutions and thereby highlighting the fight end of the coping continuum:

We are a business, we're in warfare. If we lose something, we're really upset about it. What we did was we found out why we lost it, and we knew it was price, and we then thought what the price was and we re-engineered our business to reduce costs to make sure we could pick this business up [...]. When you lose business, you learn. You actually learn an enormous amount of information and you learn from it.

Similarly, a GM of an Energy Market Solutions firm demonstrating an active hardiness response to customer loss by analyzing the reasons of defection to plan the fight strategy commented that:

First of all, we had to do our own internal evaluation to make sure that we weren't over charging the customer, that we were in accordance with the contract and how that related to what the current market [...] because the contract had been going for six years, so we had to then decide how that related to the current market position, and also what the value of that contract was to us and was it worth fighting for.

The above-mentioned two comments represent different ways in which sales professionals engage in purposeful problem-solving in response to the stress of customer loss. These highlight the active attempts to address and solve the problem at hand by deliberate rational efforts.

In contrast, $\mathrm{EFC}$ involves distancing or detaching oneself from the situation or avoiding the situation completely (Folkman et al., 1986). EFC or distancing is reflected by the quote of an Area Manager of Storage Solutions: "I kind of just left it at that, because it was too taxing, you know?" Similarly, a Mortgage and Risk Adviser of 
$\mathrm{EJM}$

$50,3 / 4$

406

Financial Services, displaying withdrawal disposition because of helplessness over the situation of customer loss, commented that:

Basically, we had felt that the ship had sailed, and no matter what we did at that point they were pretty upset. So there wasn't a lot we were going to do, and the best thing that they probably wanted from us was to leave them alone.

Another illustration of the flight end of coping continuum highlighting distancing oneself from the situation can be seen in the statement by an Owner of an Electrical Manufacturer:

There's no point in chasing a dead duck so to speak [...] so their future and current products were key and if we couldn't compete with XX (company name withheld) since it was actually Europe and European pricing, it was no point in pursuing it. Basically [...] these guys actually had factories all around Europe and basically bought this New Zealand company and took those products and added them to their current products range in other factories. So as it transpired they were never going to, you know.

The above-mentioned statements highlight the EFC response to customer defection by viewing the situation as a problem that cannot be solved, thereby displaying a negative flight reaction.

However, sometimes sales professionals use both $\mathrm{PFC}$ and $\mathrm{EFC}$ in certain situations, as these coping choices are not mutually exclusive. This was illustrated by a Managing Director of a Database Communication Services firm stating that: "There were a lot of things that sort of didn't line up and we battled, but we eventually just gave up, too hard [...]". Similarly, an Owner from the Horticulture Industry showed both a PFC response by apologizing to amend the situation and then an EFC reaction by distancing himself from the customer. Specifically, he commented that:

I arranged a casual meeting with the owner to discuss our future. And my strategy was to be apologetic and try and get him to understand that we made a mistake and we won't again. He said he would call us in a few days with maybe an order. The call came in and he said I will not be needing your supply anymore this season, perhaps maybe discuss terms next year. We felt hard done by after the promise he had shown a few days earlier. We have not heard from him since, and to be honest we weren't really expecting a call for the next season's arrangements, and we don't want to approach him first [...].

These comments clearly show that the coping choices are not mutually exclusive. Depending on the reasons for defection, at times, sales professionals would try to purposefully resolve the reasons for customer defection before finally escaping from the source of stress.

3.2.2 Justice constructs. As stated earlier, justice mechanisms were based on categorization provided by Duffy et al. (2013), Hoppner et al. (2014) and Tax et al. (1998). First, procedural justice involves active waiting, information-seeking and voice-giving processes. These processes allow sales professionals to improve existing processes, either by customization or by developing special capabilities to better serve customers' needs. While describing the attempt to provide procedural justice via monitoring the defected customer's business and tracking the competitor's shortfalls, the Director of Timber Products illustrated actively waiting to provide a new value proposition:

Probably, our intelligence gathering information [...]. Where you sense there's a few, maybe, shortages or maybe they've been let down; containers have been late, or things that they said 
were going to ship didn't ship on time [...]. But probably enough intelligence came back to say, well things weren't quite as good as they appeared to be to start with, something's changed, and then you start skirting around the edges trying to figure out what's really going on, and being their best friend again. And in this particular case, probably a phone [...] it might have even started with a phone call from them saying "Oh, can you help us with this? We need a bit of this", or "we're short of a bit of that". You sense the weakness, and then you get back into it and figure out what's really going on.

Another example of procedural justice by the President of a Consultancy Services firm showed that by providing an outlet for the defected customer to voice concerns, and by learning about and responding to its needs, he was able to establish common understanding, restore equity and rebuild trust with the customer:

It was a process of meetings with the two of the original three directors to begin with, and slowly introduce the new products and concepts to market through their channel. This eventually turned into a full product presentation to the new board of the customer, highlighting the weaknesses of their current product strategy then filling in the gaps to help complete a product package for the consumer [...]. We ended up entering the market with a different product range with the customer [...]. Customer switched back because of the new product proposition and also the relationship with two of the original directors, as well as the technical support that they realized they could not get otherwise.

These examples of procedural justice display how sales professionals engage in a process of active waiting by continuing monitoring the customer's and competitor's actions. Likewise, voice giving and restoring relationship with the defected customer by realigning value proposition are important procedural justice mechanisms.

Sales professionals use various means to win back a customer. Sometimes more than one form of justice is necessary to restore the equity in the relationship. Tax et al. (1998) suggests five potential indicators of interactional justice to win back lost customers. These include honesty, politeness, empathy, providing reasonable and consistent explanations, all directing to customer-oriented communication to win back customer. The following quote by an Account Manager from the Beverage Industry illustrated interactional justice with procedure justice by honestly communicating the mistake made on technical front and delivering a process to readdress the issue in a transparent manner:

Identifying that we had made a mistake in regards to the technical issue, and we hadn't addressed it correctly [...]. We hadn't put as much value on the issue as what they were, and it was just a case of structuring how if these issues were to occur in the future, how would we resolve them, what would we do to make sure you know were actually on top of them, and didn't pass it off as "it's a nothing issue", and it is actually a major issue. And then structuring on the win back if little things like that occur in the future, we need to jump on it straight away and find out how do we go about fixing it.

Finally, distributive justice usually takes some form of financial compensations such as price discounts, service concessions and promotion allowances. Attempts to provide distributive justice is evident from the following quote by a National Manager of a FMCG Brand Distribution Service firm:

We did really want to give this customer the best deal, so we did put in an extra promotional claim back. 
EJM

50,3/4

408

Likewise, a Sales Manager from the Meat Industry provided distributive justice by supplying free samples and engaged the defected customer in a process to display the quality of the product. Specifically, he commented that:

Well [...] we initially enticed them back by supplying free samples of the product that we would like them to buy. And when they sampled them and cooked them and served them to themselves and tried them out, they were overwhelmed by the quality, taste and tenderness. And we were able to win them back on the quality of the product and the particular style of cut.

The above-mentioned statements by sales professionals illustrate varied strategies used to provide distributive justice by either giving promotional allowances or free samples along with customizing to better serve the needs of the defected customer.

Thus, from the content analysis, we confirmed sales professionals' patterns of coping strategies (i.e. $\mathrm{PFC}$ and $\mathrm{EFC}$ ) and justice mechanisms (i.e. procedural, interactional and distributive justice) when attempting to win back lost customers. We then coded each variable for hypotheses testing using logistic regression. The combined research design of CIT with logistic regression has been applied in prior studies to assess the nature of relationship between cognitive appraisal and types of service failure (Surachartkumtonkun et al., 2013). The use of logistic regression is strongly advocated for two-group classification problems, such as successful versus unsuccessful win back. It is useful for generating more appropriate findings in terms of model fit (Akinci et al., 2007). In the current study, logistic regression helps in identifying sets of predictors to determine successful customer reacquisition (Tabachnick and Fidell, 2007).

\subsection{Profile of critical incidents}

A total of 98 completed and usable critical incidents were selected for analysis. In all, 51 cases were successful incidents and 47 cases were unsuccessful. Of all, 30 per cent of the sales firms were product related; 34 per cent services related; and the remaining 36 per cent provided both products and services. Only 20 per cent of sales firms reported having formal policies for reacquiring lost customers. For the respondents, 78 per cent were male. On average, respondents were 39 years old and had over 11 years of sales experience. The job titles of respondents were: Owner, CEO, Managing Director, GM, Sales Director, Sales Consultant, Account Manager/Executive and Marketing/Sales Representative. Of the defected customers, 39 per cent were large firms; 36 per cent medium firms; and 25 per cent small firms. The average length of the business relationship before defection was 9.4 years. Additionally, 31 per cent of defected customers had product/service customization, while 67 per cent did not (and 2 per cent did not report). See Table I for profile of critical incidents.

3.3.1 Coding of the critical incidents. We use binary logistic regressions in SPSS to test hypotheses. Win-back outcome was the dependent variable $(1=$ successful win back; $0=$ unsuccessful). Corresponding to customer reacquisition process, the independent variables were specified in two categories. The first category comprised coping strategies: PFC, EFC and experience. We coded these as high (2) and low (1). Experience above five years was coded as high (2) and below five years as low (1). The second category comprised justice mechanisms that sales professionals implement to win back lost customers. These included: procedural justice, interactional justice and distributive justice. All the justice mechanisms were coded as dichotomous variables where $1=$ used and $0=$ not used. In addition, gender was coded as $1=$ male and $2=$ female. 
Male

Female

Age (Average)

Sales experience (Average number of years)

Less than 2

Not reported

Sales firms

Product related $\quad 29.6$

$\begin{array}{ll}\text { Service related } & 33.7\end{array}$

Both product- and service-related $\quad 36.7$

Formal policy for reacquisition $\quad 19.4$

Defected customers

Relationship duration (Average number of years)

Less than 2

$2-5$

11-20

More than 20

Not reported

Size

Large

Small

Not reported

Customization

Yes

No

\section{Analysis and findings}

The results of logistic regression are presented in two sections. The first section reports the results of the relationship between coping strategies and win-back outcomes, and the second section reports the relationship between justice mechanisms and win-back outcomes. Folkman et al. (1986) implemented similar two-stage approach to examine the effect of coping and the effect of appraisal on encounter outcomes separately. We use this approach because a sales professional often moves out of coping mode into an action mode when he/she reaches out to the defected customer with forms of justice to address customer defection issues. In addition, to alleviate concerns for unaccounted variance, we included gender as a 
$\mathrm{EJM}$

$50,3 / 4$

410

control variable in the first stage of analysis and relationship length and customer size in the second stage of analysis.

\subsection{Coping strategies and win back}

In the first stage, the relationship between the two coping strategies and win-back outcome was examined. The results of logistic regression are shown in Table II. The overall fit of the model was assessed by the Hosmer and Lemeshow test, which was not significant $\left(\chi^{2}=5.84, \rho>0.001\right)$, indicating a good model (Tabachnick and Fidell, 2007). The Cox and Snell $R^{2}$ and Nagelkerke $R^{2}$ are both above 0.25 , indicating that the variables in the model account for at least a quarter of the variation in successfully winning back a lost customer (Hair et al., 2010). The classification score shows that 73.5 per cent of cases are correctly classified, which is an improvement from the base model with 52.2 per cent of correct classification. Thus, the model is accepted based on overall measures of model fit accuracy for both statistical and practical significance (Hair et al., 2010). The correlations are shown in Table III.

After this, the statistical significance of independent variables is estimated. The results provide some support for $H 1$, which stated that $\mathrm{PFC}$ is positively related to successful customer reacquisition $(H 1: \mathrm{B}=0.992, \rho<0.1$ ) with odds ratio of 2.69. In other words, a one-unit change in $\mathrm{PFC}$ would increase the probability of winning back a lost customer by 2.6 times. Although $\rho$ value is slightly higher than 0.05 ( $\rho=0.051)$, the results show that when $\mathrm{PFC}$ is included in the model, the classification score of the model is 73.5 per cent. Thus, its importance cannot be underestimated in the model. In addition, results support $\mathrm{H} 2$, which predicted that $\mathrm{EFC}$ strategies negatively influence customer reacquisition as the coefficient is negative and statistically significant $(H 2: \mathrm{B}=-2.355$, $\rho<0.001)$. Furthermore, gender as a control is not significant.

Additionally, we tested the interaction effect of sales experience on the relationship between PFC and win back, as well as EFC and win back. The results suggest that sales experience does not significantly moderate the relationship between PFC and win back. However, as predicted in $H 3$, sales experience weakens the negative relationship between $\mathrm{EFC}$ and win back $(H 3: \mathrm{B}=-1.818, \rho<0.1)$. Figure 2 suggests that highly experienced sales professionals using low EFC can increase their chances on successfully winning back a lost customer. Experience seems to help them cope better in situations of customer defection. Interestingly, the graph further suggests that more experience decreases the probability of wining back customers for sales professionals using high levels of EFC. This is probably due to these sales professionals "surviving" customer losses throughout their careers by escaping or distancing themselves from this stressor and striving for new sales. Accordingly, it seems that high levels of EFC may be reinforced with experience. This, in turn, reduces the chance of winning back a lost customer.

\subsection{Justice mechanisms and win back}

In the next stage, the relationship between justice mechanisms and win back were examined. The results are shown in Table IV. Again, the overall fit of the model was assessed by the Hosmer and Lemeshow test, which was not significant $\left(\chi^{2}=9.04, \rho>\right.$ 0.001 ), indicating a good model (Tabachnick and Fidell, 2007). The Cox and Snell $R^{2}$ and Nagelkerke $R^{2}$ are both above 0.39 , indicating that the justice mechanisms variables in the model account for more than 39 per cent of the variation in successfully winning 

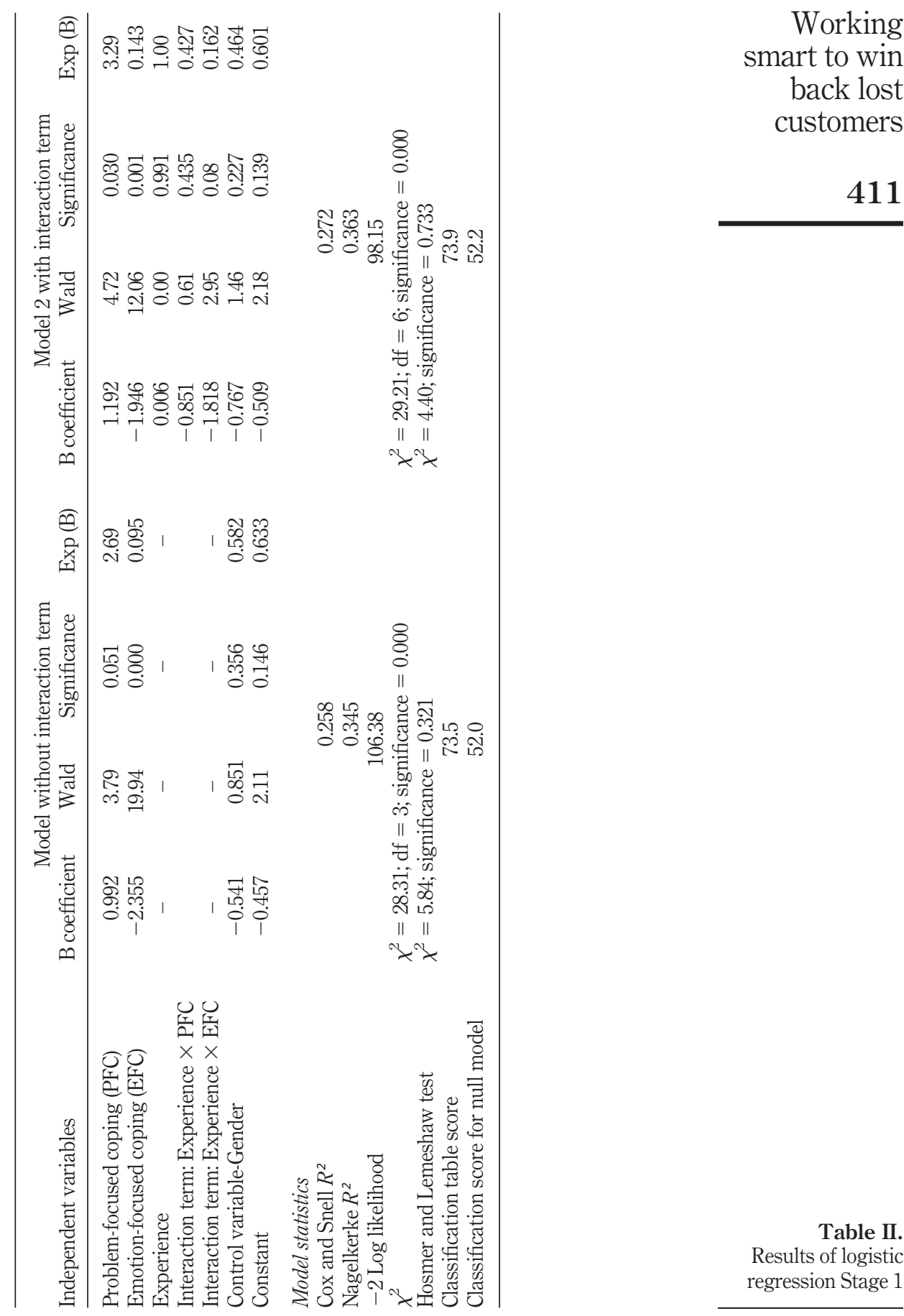

Table II.

Results of logistic regression Stage 1 
EJM

$50,3 / 4$

412

Table III.

Correlation table

Stage 1 back a lost customer (Hair et al., 2010). The classification score shows that 81.3 per cent of cases are correctly classified. Thus, the model is accepted based on overall measures of model fit accuracy for both statistical and practical significance (Hair et al., 2010). The correlation table is shown in Table $\mathrm{V}$.

The results provide support for $H 4$, which stated that procedural justice (i.e. active waiting, improving process and developing capabilities) is positively related to win $\operatorname{back}(H 4: \mathrm{B}=3.019, \rho<0.001)$ with an odds ratio of 20.47 . This suggests that one-unit change in procedural justice increases the probability of winning back a lost customer by 20 times. In addition, we found support for $H 5$ and $H 6$, which predicted that interactional justice (e.g. customer-oriented communication and providing apology) and distributive justice (e.g. price discounts, concessions and promotion allowances) are positively related to win back. Results support both hypotheses (H5: B = 3.139, $\rho<$ $0.001 ; H 6: \mathrm{B}=1.429, \rho<0.05)$. In addition, the odds ratio suggests that one-unit change in interactional justice and distributive justice increases the probability of winning back by 23 and 4 times, respectively. In comparing the B scores and odds ratio of the three justice mechanisms, we found that interactional justice and procedural justice have the stronger effect on win back. Finally, the results of two control variables suggest that relationship length and customer size do not have any significant influence in the model.

\begin{tabular}{lrrrr}
\hline & Gender & PFC & EFC & Experience \\
\hline Gender & 1.000 & & & \\
PFC & -0.108 & 1.000 & & \\
EFC & 0.359 & -0.123 & 1.000 & \\
Experience & 0.106 & -0.034 & -0.062 & 1.000 \\
\hline
\end{tabular}

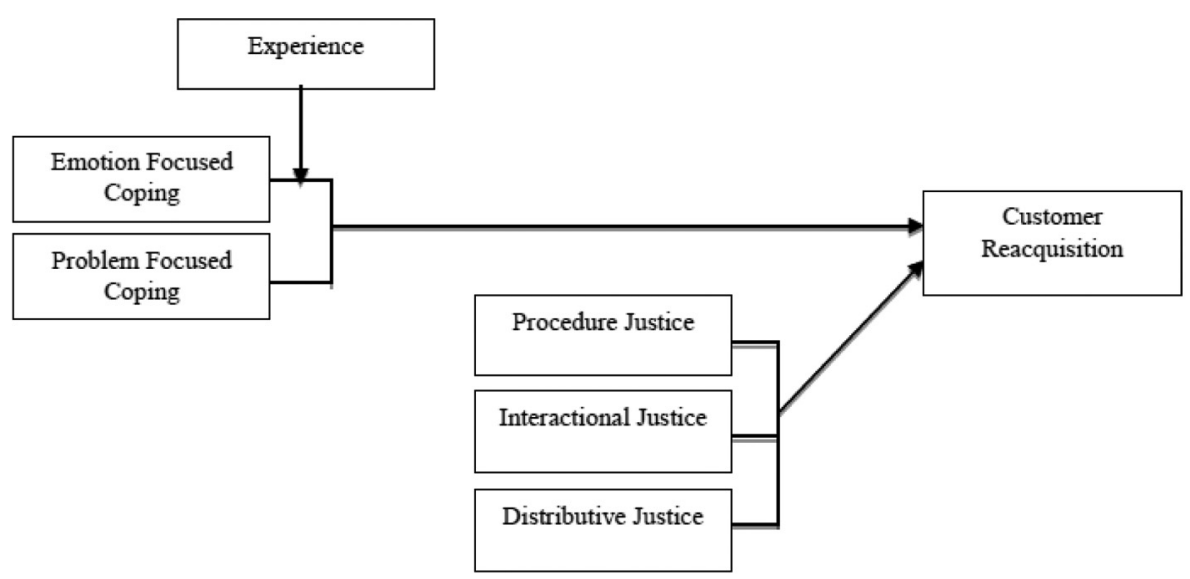

Figure 1.

Coping, justice and reacquisition outcome
Copying Mechanisms
Justice Mechanisms

Reacquisition Outcome 


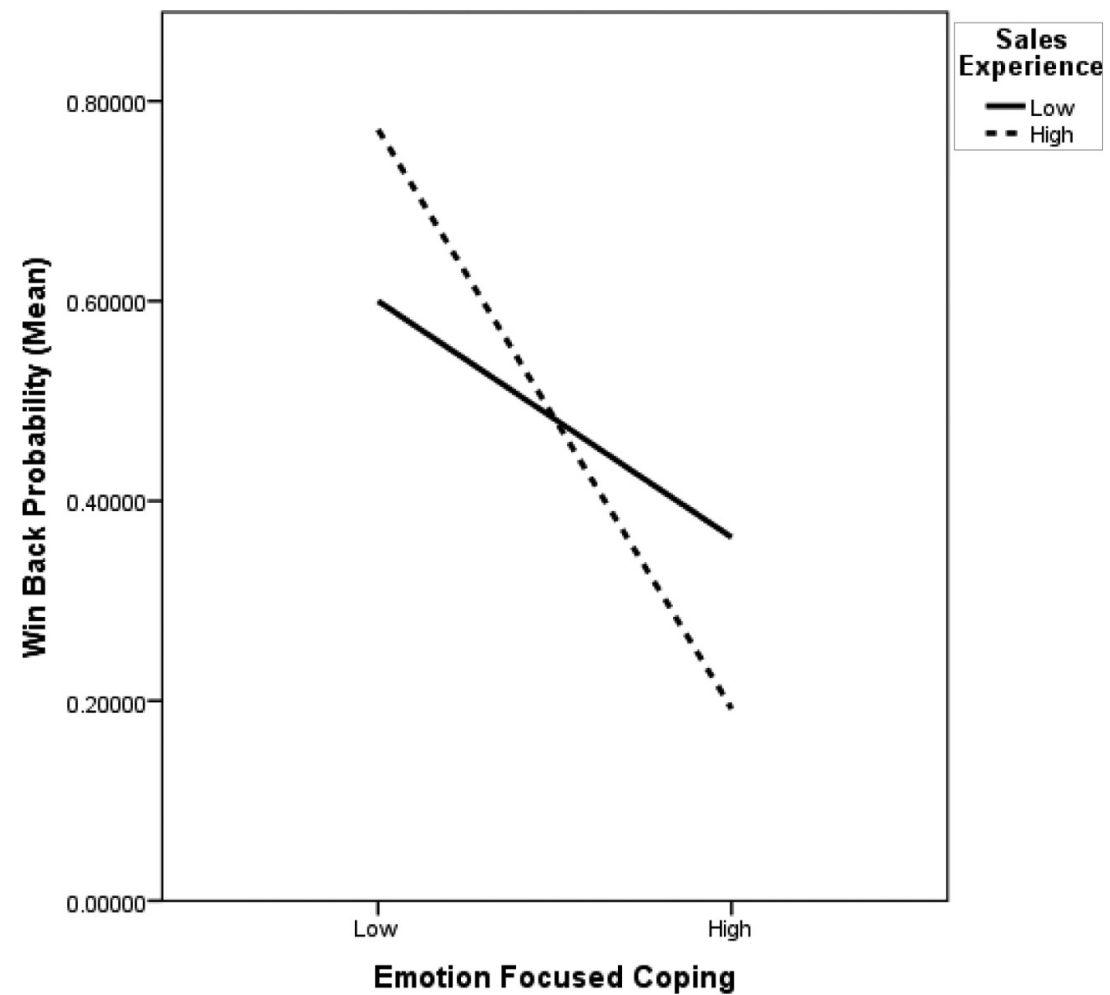

Working
smart to win
back lost
customers
413

Figure 2.

Sales experience

moderating emotion-focused coping

\begin{tabular}{|c|c|c|c|c|c|}
\hline \multirow[b]{2}{*}{ Independent variables } & \multicolumn{4}{|c|}{ Model } & \\
\hline & B coefficient & Wald & Significance & $\operatorname{Exp}(B)$ & \\
\hline Procedural justice & 3.019 & 17.25 & 0.000 & 20.47 & \\
\hline Interactional justice & 3.139 & 15.97 & 0.000 & 23.08 & \\
\hline Distributive justice & 1.429 & 5.28 & 0.021 & 4.17 & \\
\hline \multicolumn{6}{|l|}{ Control variables } \\
\hline Relationship length & 0.206 & 0.118 & 0.732 & 1.22 & \\
\hline Customer size & -0.123 & 0.041 & 0.839 & 0.885 & \\
\hline Constant & -3.93 & 17.57 & 0.000 & 0.019 & \\
\hline \multicolumn{6}{|l|}{ Model statistics } \\
\hline Cox and Snell $R^{2}$ & \multicolumn{4}{|c|}{0.393} & \\
\hline Nagelkerke $R^{2}$ & \multirow{2}{*}{\multicolumn{4}{|c|}{0.525}} & \\
\hline -2Log likelihood & & & & & \\
\hline$\chi^{2}$ & \multicolumn{5}{|c|}{$\chi_{\mathrm{o}}^{2}=45.46 ; \mathrm{df}=5 ;$ significance $=0.000$} \\
\hline Hosmer and Lemeshaw test & \multicolumn{4}{|c|}{$\chi^{2}=9.04 ;$ significance $=0.328$} & Table IV. \\
\hline Classification table score & \multirow{2}{*}{\multicolumn{4}{|c|}{$\begin{array}{l}81.3 \\
527\end{array}$}} & Results of logistic \\
\hline Classification score for null model & & & & 52.7 & regression Stage 2 \\
\hline
\end{tabular}


EJM

$50,3 / 4$

414

Table V.

Correlation matrix

Stage 2

\section{Discussion}

This study contributes to the principles and practices of customer defection management in a number of important ways that may also lead to the rethinking and redesigning of conventional sales training. First, we add to previous research in sales' stressors and coping by confirming the operational advantages of PFC and extending its reach to win back. Second, we increase insights into how sales professionals using PFC and $\mathrm{EFC}$ view the acute stressor of losing a current customer. Recognizing that sales professionals using EFC often interpret this as a negative life event and then go into overdrive to acquire new accounts (Goodwin et al., 1997), sales training programs that focus solely on new accounts may be blinding sales professionals to the essential dynamics of the market place and, by this, inadvertently promoting EFC. If sales professionals define the business ecosystem as having only one input and outcome, then they will be less likely to scan their current customers or the B2B ecosystem for signs of potential turbulence and defection - and have even less sense of how to respond to customer loss. Our finding suggests that more experienced sales professionals using

\begin{tabular}{lccccc}
\hline & Relationship age & $\begin{array}{c}\text { Customer } \\
\text { size }\end{array}$ & $\begin{array}{c}\text { Procedural } \\
\text { justice }\end{array}$ & $\begin{array}{c}\text { Interactional } \\
\text { justice }\end{array}$ & $\begin{array}{c}\text { Distributive } \\
\text { justice }\end{array}$ \\
\hline Relationship age & 1.000 & & & & \\
Customer size & -0.132 & 1.000 & & & \\
Procedural justice & 0.026 & -0.162 & 1.000 & & \\
Interactional justice & 0.016 & -0.147 & 0.608 & 1.000 & \multirow{2}{*}{0.000} \\
Distributive justice & -0.060 & -0.123 & 0.289 & 0.175 & \\
\hline
\end{tabular}

Table VII.

Frequency table Stage 2
Frequency

Win back successful

Win back unsuccessful

PFC (low)

PFC (high)

EFC (low)

Table VI.

Frequency table Stage 1

\section{N} 51

$\begin{array}{ll}\text { Experience (above } 5 \text { years) } & 61\end{array}$

\begin{tabular}{lr} 
Frequency & $N$ \\
\hline Procedural justice (used) & 48 \\
Procedural justice (not used) & 50 \\
Interactional justice (used) & 66 \\
Interactional justice (not used) & 32 \\
Distributive justice (used) & 28 \\
Distributive justice (not used) & 70 \\
Relationship length (5 years and below) & 67 \\
Relationship length (above 5 years) & 25
\end{tabular}


high levels of EFC tend to "give up" on pursuing win back than less experienced sales professionals. By contrast, less experienced sales professionals with low levels of EFC tend to work to win back lost customers.

Second, looking at the process of external response, our findings show a strong support for procedural, interactional and distributive justice in customer reacquisition. Specifically, the results show a strong support for interactional and procedural justice. Sales professionals who pursue active waiting or improve existing processes can successfully activate defected customers switch-back behavior. These actions signify consistency and establish shared expectations and sense-making of the utility and future of the exchange relationship. The negative ramifications from the highly experienced sales professionals who "give up" rather than "re-up" defected customers is further underscored by our findings on the importance of procedural and interactional justice in customer reacquisition (another contribution to this field). Procedural justice encompasses, enlightens and enriches many of the sense and respond values, skills and processes originally applied to develop the customer (Brock et al., 2013; Brown et al., 2006; Griffith et al., 2006). With this in mind, who would be better to lead the delivery of procedural justice in win back than an experienced sales professional? Yet our research suggests that some highly experienced sales persons who are also high in EFC may avoid, falter or fail in win back. So why the apparent disconnect? We suggest this may be due to some sales training systems - and some veteran sales professionals' coping strategies - being developed in a simpler B2B sales environment than today's - and certainly the future's.

\subsection{Managerial implications}

Because of globalization, faster search and contact engines and e-commerce networks and social media, the $\mathrm{B} 2 \mathrm{~B}$ ecosystem is increasingly dynamic, competitive and discontinuous. And it will be more so as the "Internet of Things" exponentially expands customer information and contact systems. Given this, it may be fair to say that every new account is likely a defected customer from another firm. This means that many "new" customers already know how to cease and switch their purchasing. Accordingly, we suggest that sales training reflect the new "in and out" B2B ecosystem. This way, customer loss is both anticipated and responded to with first, continuing win-back-like "adaptive selling" before an avoidable loss (Sujan et al., 1994) and, second, customized defection management if a loss occurs (Griffin, 2007).

This recommended reengineering of sales training to integrate understanding and anticipation of customer cycles is a twenty-first-century approach to "Working Smarter" (Sujan et al., 1994). But as Griffin points out in her recent survey (2007), customer defection management has gone from "bad to worse" since her and Griffin and Lowenstein's (2001) efforts to improve it at the turn of the century. While no one goes into business to lose customers, without sufficient training to apply and integrate adaptive selling skills to win back, it is understandable that some B2B sales professionals view customer defection as divorce or bereavement (Goodwin et al., 1997). Naletelich et al. (2014) concludes their study on sales stress and coping by suggesting managers to develop a "phased sales training curriculum that builds salespeople's capacity for "problem solving" defined by "[...] trends in the industry and about what needs drive customers' purchasing behavior". The authors reason that this "may lessen external orientations and thus enhance use of PFC" (Naletelich et al., 2014, p. 10). We add 
$\mathrm{EJM}$

$50,3 / 4$

416

that lost customers and win back need to be anticipated as part of the B2B sales profession and be supported by justice-focused training, policies and support resources and motivation and rewards for both the effort and the wins (Leach and Liu, 2014).

The previously noted similarities between PFC versus EFC and learning versus performance orientations in goal and achievement situations further informs these recommendations. Education and classroom research suggests older students focus more on the explicit learning goals of educational institutions and skills development for a complex world - yet younger ones are more disposed to performance-driven behaviors, which lead to maladaptive responses to negative feedback (Morris et al., 2003). It appears that the more "life experiences" and "life lessons" a student has, the more he/she understands the goal of education is learning, that learning improves problem-solving and that preparation for a complex world can lead to life success. Reasoning from this findings to sales, the more sales professionals see that learning about customer cycles in an increasing dynamic B2B ecosystems - including both the threat and reality of customer defection - can lead to sales success - including retention and win back - the less they may default to EFC when encountering customer defection.

\subsection{Limitations and future research}

Several limitations in our study recommend further research to refine the concepts and reasons for $\mathrm{PFC}$ and $\mathrm{EFC}$; develop more lessons learned and best practices in justice-focused customer defection management; and formulate new training program to further adaptive sales forces that can work smarter in churning B2B ecosystems. First, as we only interviewed sales professionals and not their defected customers, we do not have the full "story" on the "why" of the losses and the "if" and "how" win back was possible and/or effective. Dyadic interviews will greatly inform and improve the findings and resulting insights. Tracking interviews with defected customers can also refine sales professionals' design and delivery of distributional, procedural and interactional justice. Furthermore, it is realistic to expect that both coping strategies are present for sales professionals and that the positive effects of PFC might be buffered (or even decreased under higher levels of EFC) or vice versa. Accordingly, we suggest that the future research should look into $\mathrm{PFC}$ and $\mathrm{EFC}$ interactions and the interplay between various coping strategies and justice mechanisms. Finally, a systematic survey to examine the ability of sales professional, the training received, their past experiences with defection, their range of coping choices, their proficiency and use of justice mechanisms and the focal customers' reasons for leaving can affirm and extend our findings. Future research can dig deeper into the complex processes that determine how $\mathrm{B} 2 \mathrm{~B}$ sales professionals can best cope and respond with justice to unwelcome changes by customers.

\section{References}

Akinci, S., Kaynak, E., Atilgan, E. and Aksoy, S. (2007), "Where does the logistic regression analysis stand in marketing literature? A comparison of the market positioning of prominent marketing journals", European Journal of Marketing, Vol. 41 Nos 5/6, pp. 537-567.

Alexander, S. and Ruderman, M. (1987), "The role of procedural and distributive justice in organizational behavior", Social Justice Research, Vol. 1 No. 2, pp. 177-198. 
Becker, D. (2013), One Nation under Stress: The Trouble with Stress as an Idea, Oxford University Press, Oxford.

Behrman, D.N. and Perreault, W.D., Jr (1984), "A role stress model of the performance and satisfaction of industrial salespersons", Journal of Marketing, Vol. 48 No. 4, pp. 9-21.

Beugré, C.D. (1998), Managing Fairness in Organizations, Quorum Books, Westport, CT.

Bitner, M.J., Booms, B.H. and Mohr, L.A. (1994), "Critical service encounters: the employee's viewpoint”, Journal of Marketing, Vol. 58 No. 4, pp. 95-106.

Bitner, M.J., Booms, B.H. and Tetreault, M.S. (1990), "The service encounter: diagnosing favorable and unfavorable incidents", Journal of Marketing, Vol. 54 No. 1, pp. 71-84.

Blaney, P.H. (2013), "Stress and depression in adults: a critical review", in Field, T.M., McCabe, P.M. and Schneiderman, N. (Eds), Stress and Coping, Psychology Press, pp. 263-284.

Blodgett, J.G., Hill, D.J. and Tax, S.S. (1997), "The effects of distributive, procedural, and interactional justice on post complaint behavior", Journal of Retailing, Vol. 73 No. 2, pp. 185-210.

Brock, C., Blut, M., Evanschitzky, H. and Kenning, P. (2013), "Satisfaction with complaint handling: a replication study on its determinants in a business-to-business context", International journal of research in marketing, Vol. 30 No. 3, pp. 319-322.

Brown, J.R., Cobb, A.T. and Lusch, R.F. (2006), "The roles played by inter organizational contracts and justice in marketing channel relationships", Journal of Business Research, Vol. 59 No. 2, pp. 166-175.

Choi, B. and Choi, B.J. (2014), "The effects of perceived service recovery justice on customer affection, loyalty and word-of-mouth", European Journal of Marketing, Vol. 48 Nos 1/2, pp. 108-131.

Colquitt, J.A., Conlon, D.E., Wesson, M.J., Porter, C.O.L.H. and Ng, K.Y. (2001), "Justice at the millennium: a meta-analytic review of 25 years of organizational justice research", Journal of Applied Psychology, Vol. 86 No. 3, pp. 425-445.

DeGeest, D. and Brown, K.G. (2011), "The role of goal orientation in leadership development", Human Resource Development Quarterly, Vol. 22 No. 2, pp. 157-175.

Dubois, A. and Gibbert, M. (2010), "From complexity to transparency: managing the interplay between theory, method and empirical phenomena in IMM case studies", Industrial Marketing Management, Vol. 39 No. 1, pp. 129-136.

Duffy, R., Fearne, A., Hornibrook, S., Hutchinson, K. and Reid, A. (2013), "Engaging suppliers in CRM: the role of justice in buyer-supplier relationships", International Journal of Information Management, Vol. 33 No. 1, pp. 20-27.

Eisenhardt, K.M. (1989), "Building theories from case study research", Academy of Management Review, Vol. 14 No. 4, pp. 532-550.

Folger, R. and Skarlicki, D.P. (1999), "Unfairness and resistance to change: hardship as mistreatment”, Journal of Organizational Change Management, Vol. 12 No. 1, pp. 35-50.

Folkman, S., Lazarus, R.S., Dunkel-Schetter, C., DeLongis, A. and Gruen, R.J. (1986), "Dynamics of a stressful encounter: cognitive appraisal, coping, and encounter outcomes", Journal of Personality and Social Psychology, Vol. 50 No. 5, pp. 992-1003.

Goodwin, C., Mayo, M. and Hill, R.P. (1997), "Salesperson response to loss of a major account: a qualitative analysis”, Journal of Business Research, Vol. 40 No. 2, pp. 167-180.

Goolsby, J.R. (1992), "A theory of role stress in boundary spanning positions of marketing organizations", Journal of the Academy of Marketing Science, Vol. 20 No. 2, pp. 155-164. 
$\mathrm{EJM}$

$50,3 / 4$

Griffin, J. (2007), “The state of customer win-back”, available at: www.docstoc.com/docs/ 27936816/The-State-of-Customer-Win-back (accessed 4 May 2015).

Griffin, J. and Lowenstein, M.W. (2001), Customer Winback: How to Recapture Lost CustomersAnd Keep Them Loyal, John Wiley \& Sons, New York, NY.

Griffith, D.A., Harvey, M.G. and Lusch, R.F. (2006), "Social exchange in supply chain relationships: the resulting benefits of procedural and distributive justice", Journal of Operations Management, Vol. 24 No. 2, pp. 85-98.

Hair, J.F. Jr, Black, W.C., Babin, B.J. and Anderson, R.E. (2010), Multivariate Data Analysis: A Global Perspective, Pearson Education, Upper Saddle Rive.

Hoffman, K.D. and Kelley, S.W. (2000), "Perceived justice needs and recovery evaluation: a contingency approach”, European Journal of Marketing, Vol. 34 Nos 3/4, pp. 418-432.

Homburg, C. and Fürst, A. (2005), "How organizational complaint handling drives customer loyalty: an analysis of the mechanistic and the organic approach”, Journal of Marketing, Vol. 69 No. 3, pp. 95-114.

Hoppner, J.A., Griffith, D. and Yeo, C. (2014), "The intertwined relationships of power, justice and dependence", European Journal of Marketing, Vol. 48 Nos 9/10, pp. 1690-1708.

Johnston, W.J., Leach, M.P. and Liu, A.H. (1999), "Theory testing using case studies in business-to-business research”, Industrial Marketing Management, Vol. 28 No. 3, pp. 201-213.

Kabat-Zinn, J. (2013), Full Catastrophe Living: Using the Wisdom of your Body and Mind to Face Stress, Pain, and Illness, Random House Publishing Group, New York, NY.

Kolb, D.M. and Williams, J. (2001), "Breakthrough bargaining”, Harvard Business Review, Vol. 79 No. 2, pp. 88-97.

Korsgaard, M.A., Schweiger, D.M. and Sapienza, H.J. (1995), "Building commitment, attachment, and trust in strategic decision-making teams: the role of procedural justice", Academy of Management Journal, Vol. 38 No. 1, pp. 60-84.

Kumar, N., Scheer, L.K. and Steenkamp, J.B.E.M. (1995), "The effects of supplier fairness on vulnerable resellers”, Journal of Marketing Research, Vol. 32 No. 1, pp. 54-65.

Lazarus, R.S. and Folkman, S. (1984), Stress, Appraisal, and Coping, Springer Publishing Company, New York, NY.

Leach, M.P. and Liu, A.H. (2014), "It ain't over 'til it's over: evaluating reacquisition opportunities in business-to-business markets", Industrial Marketing Management, Vol. 43 No. 4, pp. 573-581.

Lewin, J.E. and Sager, J.K. (2008), "Salesperson burnout: a test of the coping-meditational model of social support”, Journal of Personal Selling and Sales Management, Vol. 28 No. 3, pp. 233-246.

Lewin, J.E. and Sager, J.K. (2009), "An investigation of the influence of coping resources in salespersons' emotional exhaustion”, Industrial Marketing Management, Vol. 38 No. 7 , pp. 798-805.

Lewin, J.E. and Sager, J.K. (2010), “The influence of personal characteristics and coping strategies on salespersons' turnover intentions", Journal of Personal Selling and Sales Management, Vol. 30 No. 4, pp. 355-370.

Liu, A.H., Leach, M.P. and Chugh, R. (2015), "A sales process framework to regain B2B customers", Journal of Business and Industrial Marketing, Vol. 30 No. 8.

Liu, Y., Huang, Y., Luo, Y. and Zhao, Y. (2012), "How does justice matter in achieving buyer-supplier relationship performance?", Journal of Operations Management, Vol. 30 No. 5, pp. 355-367. 
Mallin, M.L. and Mayo, M. (2006), "Why did I lose? A conservation of resources view of salesperson failure attributions", Journal of Personal Selling and Sales Management, Vol. 26 No. 4, pp. 345-357.

Mallin, M.L. and Mayo, M. (2010), "The impact of sales failure on attributions made by "resource-challenged' and 'resource-secure" salespeople", Journal of Marketing Theory and Practice, Vol. 18 No. 3, pp. 233-248.

Monin, P., Noorderhaven, N., Vaara, E. and Kroon, D. (2012), “Giving sense to and making sense of justice in post-merger integration”, Academy of Management Journal, Vol. 56 No. 1, pp. 256-284.

Morris, E.A., Brooks, P.R. and May, J.L. (2003), "The relationship between achievement goal orientation and coping style: traditional vs non-traditional college students", College Student Journal, Vol. 37 No. 1, p. 3.

Naletelich, K., Sager, J.K., Dubinsky, A.J. and Srivastava, R. (2014), “A model of the determinants and outcomes of salespeople's coping style", International Journal of Business and Management, Vol. 9 No. 6, pp. 1-19.

Newberg, A.B. and Waldman, M.R. (2012), Words can Change your Brain: 12 Conversation Strategies to Build Trust, Resolve Conflict and Increase Intimacy, Hudson Street Press Penguin Group, New York, NY.

Reichheld, F.F. (1996), "Learning from customer defections”, Harvard Business Review, Vol. 74 No. 2, pp. 56-69.

Schneiderman, N. and McCabe, P.M. (2013), "Biobehavioral responses to stressors", in Field, T.M., McCabe, P.M. and Schneiderman, N. (Eds), Stress and Coping, Psychology Press, Abingdon, pp. 13-61.

Schwepker, C.H., Jr. and Good, D.J. (2012), "Sales quotas: unintended consequences on trust in organization, customer-oriented selling, and sales performance", Journal of Marketing Theory and Practice, Vol. 20 No. 4, pp. 437-452.

Sparks, B.A. and Callan, V.J. (1997), "Service breakdowns and service evaluations: the role of customer attributions", Journal of Hospitality and Leisure Marketing, Vol. 4 No. 2, pp. 3-24.

Sparks, B.A. and McColl-Kennedy, J.R. (2001), "Justice strategy options for increased customer satisfaction in a services recovery setting", Journal of Business Research, Vol. 54 No. 3, pp. 209-218.

Srivastava, R. and Sager, J.K. (1999), "Influence of personal characteristics on salespeople's coping style" Journal of Personal Selling and Sales Management, Vol. 19 No. 2, pp. 47-57.

Strutton, D. and Lumpkin, J.R. (1993), "The relationship between optimism and coping styles of salespeople", Journal of Personal Selling and Sales Management, Vol. 13 No. 2, pp. 71-82.

Sujan, H., Weitz, B.A. and Kumar, N. (1994), "Learning orientation, working smart, and effective selling”, Journal of Marketing, Vol. 58 No. 3, pp. 39-52.

Surachartkumtonkun, J., Patterson, P.G. and McColl-Kennedy, J.R. (2013), "Customer rage back-story: linking needs-based cognitive appraisal to service failure type", Journal of Retailing, Vol. 89 No. 1, pp. 72-87.

Tabachnick, B.G. and Fidell, L.S. (2007), Using Multivariate Statistics, Pearson Education, Boston, MA.

Tapp, J.T. (2013), "Multisystems holistic model of health”, in Field, T.M., McCabe, P.M. and Schneiderman, N. (Eds), Stress and Coping, Psychology Press, Abingdon, pp. 285-304.

Tax, S.S. and Brown, S.W. (1998), "Recovering and learning from service failure", Sloan Management, Vol. 40 No. 1, pp. 75-88. 
EJM

$50,3 / 4$

Tax, S.S., Brown, S.W. and Chandrashekaran, M. (1998), "Customer evaluations of service complaint experiences: implications for relationship marketing”, Journal of Marketing, Vol. 62 No. 2, pp. 60-76.

Wilkinson, S. (2004), "Focus group research", in Silverman, D (Ed.), Qualitative Research: Theory, Method and Practice, Sage Publications, London, pp. 177-199.

\section{About the authors}

Annie H. Liu is an Associate Professor in Marketing at Texas State University. Her areas of expertise and research mainly focus on B2B networks, including B2B marketing and sales, customer retention and reacquisition, international marketing and cross cultural networks. She has published in Industrial Marketing Management, Journal of Business Research, Journal of Marketing Theory \& Practice, Journal of Business \& Industrial Marketing, Journal of Business-to-Business Marketing and Journal of Personal Selling \& Sales Management. Dr Liu received her $\mathrm{PhD}$ from Georgia State University. Annie H. Liu is the corresponding author and can be contacted at: aliu@txstate.edu

Richa Chugh is a Doctoral Candidate at Victoria University, NZ. Her research interests involve work addressing buyer-supplier relationships, export performance and customer reacquisition. She has published in Journal of Business \& Industrial Marketing.

Albert Noel Gould is a Professor in Management at the University of Wisconsin, Eau Claire. He is the Founding Chair and CEO of the Virtual Trade Mission Foundation, a Leader in Global Learning for Global Leadership throughout the Asia Pacific Economic Cooperation (APEC) system. He is a frequent Guest Lecturer and Seminar Director at universities around the Pacific Rim, focusing on global B2B networks, Asia Pacific markets and collaborative leadership/ management models for the emergent multi-polar world. He has published in IndustrialMarketing Management. Dr Gould received his JD from UC Berkeley.

For instructions on how to order reprints of this article, please visit our website: www.emeraldgrouppublishing.com/licensing/reprints.htm Or contact us for further details: permissions@emeraldinsight.com 